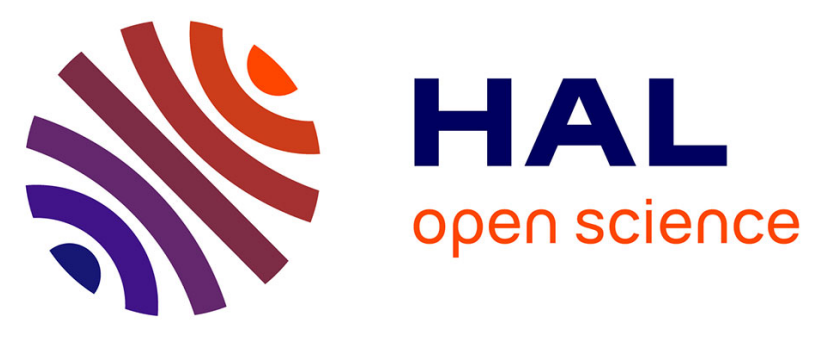

\title{
Influence of the electrografting method on the performances of a flow electrochemical sensor using modified electrodes for trace analysis of copper (II).
}

Bogdan Feier, Ionel Fizesan, Cristelle Mériadec, Soraya Ababou-Girard, Cecilia Cristea, Robert Sandulescu, Florence Geneste

\section{To cite this version:}

Bogdan Feier, Ionel Fizesan, Cristelle Mériadec, Soraya Ababou-Girard, Cecilia Cristea, et al.. Influence of the electrografting method on the performances of a flow electrochemical sensor using modified electrodes for trace analysis of copper (II).. Journal of electroanalytical chemistry and interfacial electrochemistry, 2015, 744, pp.1-7. 10.1016/j.jelechem.2015.02.032 . hal-01151353

HAL Id: hal-01151353

https://hal-univ-rennes1.archives-ouvertes.fr/hal-01151353

Submitted on 29 Oct 2015

HAL is a multi-disciplinary open access archive for the deposit and dissemination of scientific research documents, whether they are published or not. The documents may come from teaching and research institutions in France or abroad, or from public or private research centers.
L'archive ouverte pluridisciplinaire HAL, est destinée au dépôt et à la diffusion de documents scientifiques de niveau recherche, publiés ou non, émanant des établissements d'enseignement et de recherche français ou étrangers, des laboratoires publics ou privés. 
Influence of the electrografting method on the performances of a flow electrochemical sensor using modified electrodes for trace analysis of copper (II)

Bogdan Feier ${ }^{\mathrm{a}, \mathrm{b}}$, Ionel, Fizesan ${ }^{\mathrm{a}, \mathrm{b}}$, Cristelle Mériadec ${ }^{\mathrm{c}}$, Soraya Ababou Girard ${ }^{\mathrm{c}}$, Cécilia Cristea $^{\mathrm{b}}$, Robert Sandulescu ${ }^{\mathrm{b}}$, Florence Geneste ${ }^{\mathrm{a}^{*}}$

${ }^{\text {a } U M R-C N R S ~ 6226, ~ I n s t i t u t e ~ o f ~ C h e m i c a l ~ S c i e n c e s ~ o f ~ R e n n e s, ~ U n i v e r s i t y ~ o f ~ R e n n e s ~ 1, ~ T e a m ~}$ MaCSE, Beaulieu Campus, 35042 Rennes Cedex, France

b "Iuliu Hatieganu" University of Medicine and Pharmacy, Faculty of Pharmacy, Department of Analytical Chemistry, 4 Pasteur str, 400012 Cluj-Napoca, Romania

c Institute of Physics of Rennes, University of Rennes 1, UMR-CNRS 6251, Beaulieu Campus, 35042 Rennes cedex, France

\begin{abstract}
The performances of carboxylate- and cyclam-modified graphite felt electrodes prepared by different electrografting methods for trace analysis of copper (II) were compared to determine the influence of the immobilization process of the linkers on the sensor properties. The derivatization performed by cathodic reduction of diazonium salts and by anodic oxidation of amines in organic and aqueous media was first evaluated by cyclic voltammetry and X-ray photoelectron spectroscopy analyses, showing a higher surface coverage for the reduction process. Cyclam was subsequently attached on the COOH-modified graphite felts by a coupling reaction. The modified electrodes were then employed in a flow analytical system for trace analysis of copper (II) ions. The influence of the surface coverage and the nature of the linker on the electrochemical signal obtained by linear sweep stripping voltammetry analysis after a preconcentration step performed at open circuit was highlighted. The selectivity estimated in the presence of lead used as a common ion interferent was higher when a selective receptor was used and depends on the nature of the linker.
\end{abstract}

Keywords: open circuit preconcentration, sensor, cyclam, copper detection, electrografting

\footnotetext{
${ }^{*}$ Corresponding author: Tel.: +332 23235965; Fax.:+332 23235967

E-mail address: Florence.Geneste@univ-rennes1.fr (F. Geneste)
} 


\section{Introduction}

Heavy metals are pollutant elements that could be present both in natural and contaminated environments resulting in potential public health problems. Human contamination could originate from many different sources such as water, food but also from medicines and cosmetics. The most conventional methods used to quantify heavy metals at trace level are ionic chromatography and inductive coupling plasma with mass spectrometry (ICP/MS) that allow the detection of several ions in one analysis with concentrations lower than $0.1 \mu \mathrm{g} / \mathrm{L}[1$, 2]. However, these efficient methods display some drawbacks like expensive laboratory instruments and difficulty to perform rapid field analyses. Electrochemical analysis is fast, can provide low-cost multi-analytic sensor able to detect a wide variety of pollutants and can easily be miniaturized to achieve portable sensors. However, electrochemical analysis at trace level requires an accumulation step usually consisting in the adsorption of the analyte on a modified electrode. Among all the methods that have been applied to preconcentrate heavy metals on the electrode [3], the use of specifically designed ligands allowing the formation of stable complexes on the surface of the electrode has best proved its efficiency in terms of selectivity and sensitivity [4-12]. Different procedures have been used to prepare receptormodified electrodes such as the incorporation in a Nafion film used as an electrostatic binding medium [13-15], the intercalation in montmorillonite [16], the covalent attachment on a silica matrix used in a carbon paste electrode [17-20] or coated as a thin film on its surface [21, 22], and the direct attachment by electropolymerisation [23, 24] or electrografting methods [2530]. In case of encapsulation, the influence of the matrix on the electrochemical signal has been evidenced [31]. It has also been shown that the conditions of film coating can dramatically affect the performances of the sensor [22]. For electrografting methods, if the role of the ligand in improving the performances of the sensor is expected, the influence of the immobilization method has not been clearly evidenced.

To achieve continuous, real-time detection of aqueous analytes, 3D- carbon structures are interesting as they overcome the limitations imposed by diffusion and mass transport in bringing the target molecules to the sensor surface. In this connection, we have recently demonstrated the large interest and shown the specific advantages of graphite felt electrodes for applications in flow electroanalysis [10, 11, 29, 30, 32]. This material of high surface area presents good conductivity and excellent hydrodynamic properties due to its high void volume of around $90 \%$. The percolation of the solution through the electrode increases the kinetics of binding/complexation between the target analyte and the surface compared to 
static systems, leading to a much more efficient association step. Additionally, the volume of the analyte solution in contact with the electrode is well controlled in a flow system.

Due to the use of a flow system, the immobilization of the receptor on the electrode has been achieved by covalent attachment to avoid leaching during the flow preconcentration step. The covalent attachment was obtained by electrografting a linker on the surface of the electrode, followed by chemical reaction between the immobilized linker and the receptor. Electrografting methods such as the reduction of diazonium salts [30] and the oxidation of primary amines $[11,29]$ that can be controlled electrochemically have proved their efficiency to achieve flow electrochemical sensors. However, these immobilization processes can affect the performances of the flow sensor; cathodic reduction of diazonium salts often leads to the formation of multilayers [33] that can decrease the electron transfer and thus the efficiency of the transduction signal, and anodic oxidation of monoamines gives submonolayer coverage of the electrode surface [34] avoiding the attachment of a high amount of receptors.

In this work, we studied the influence of the electrografting method on the performances in terms of sensitivity and selectivity of a flow sensor for copper (II) detection. Since cyclammodified electrodes have already shown their interest as receptor for copper (II) detection [35], the covalent immobilization of cyclam on the 3D electrode was achieved by electrografting methods involying the reduction of diazonium salts and the oxidation of amines. Carboxylate linkers were used as intermediate for the derivatization of the electrode surface, cyclam being subsequently introduced by a coupling reaction. Cylam- and also carboxylate-modified electrodes were tested for copper (II) detection due to the known complexing properties of $\mathrm{COO}^{-}$groups for heavy metals [10].

\section{Experimental section}

\subsection{Reagents and materials}

The graphite felt was obtained from Mersen, France (RVG 4000). Its specific area measured by the BET method is $0.7 \mathrm{~m}^{2} \mathrm{~g}^{-1}$ and its density is $0.088 \mathrm{~g} \mathrm{~cm}^{-3}$. The diameter of a fiber is around $20 \mu \mathrm{m}$. Lead(II) nitrate, anhydrous copper (II) chloride, 5-aminopentanoic acid, 1,4,8,11-tetrazacyclotetradecane (cyclam) and sodium tetrafluoroborate were purchased from Acros and diethylaminosulfur trifluoride (DAST), 4-nitrobenzylamine hydrochloride and methyl 6-aminohexanoate hydrochloride from Aldrich. 4-carboxymethyl-benzenediazonium salts was prepared according to literature and stored under argon in a freezer [36]. All solutions were prepared with ultrapure water (18.2 M $\Omega$, Millipore Simplicity). All glassware 
and flow reactor were rinsed with a $10 \% \mathrm{HNO}_{3}$ solution followed by ultrapure water before use to avoid metal contamination.

\subsection{Preparation of the modified electrodes}

The immobilization of the receptor was performed in two steps: the electrografting of the $\mathrm{COOH}$-functionalized linker and the covalent binding of cyclam by a coupling reaction. The covalent attachment of the linker onto the electrode (48 mm diameter, $6 \mathrm{~mm}$ thickness) was performed in a divided flow cell $[37,38]$ by three methods:

- $67 \mathrm{mg}$ of 5-amino-pentanoic acid dissolved in $500 \mathrm{~mL}$ of a pH 10.3 carbonate buffer solution $\left(\mathrm{Na}_{2} \mathrm{CO}_{3} 0.25 \mathrm{M} ; \mathrm{NaHCO}_{3} 0.25 \mathrm{M}\right)$ were oxidized at $0.8 \mathrm{~V}_{\text {SCE }}$ under nitrogen, using a graphite felt as working-electrode (flow rate: $3 \mathrm{~mL} \mathrm{~min}^{-1}$ ). The electrolysis time was fixed to $2 \mathrm{~h}$ for investigations of the sensor performances.

- $300 \mathrm{mg}$ of methyl 6-aminohexanoate in $300 \mathrm{~mL}$ of $0.5 \mathrm{M} \mathrm{Bu}_{4} \mathrm{NBF}_{4}$ acetonitrile (HPLC grade) were oxidized at $1.2 \mathrm{~V}_{\mathrm{SCE}}$ for $1 \mathrm{~h}$, using a graphite felt as working-electrode (flow rate: $2 \mathrm{~mL} \mathrm{~min}^{-1}$ ). The derivatized graphite felt was ultrasonicated 3 times in acetonitrile for $15 \mathrm{~min}$ and dried under vacuum. The saponification of the amino ester grafted at the surface of the electrode was performed with 0.1 $\mathrm{M} \mathrm{NaOH}$ at room temperature for 3h [34].

- $100 \mathrm{mg}$ of 4-carboxymethyl-benzenediazonium salts, dissolved in $100 \mathrm{~mL}$ of degassed $\mathrm{HCl}$ $0.5 \mathrm{M}$ were reduced at $-0.2 \mathrm{~V}_{\mathrm{SCE}}$ for 5 min under nitrogen, using a graphite felt as working-

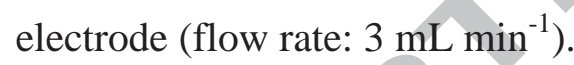

After the grafting process, the graphite felts were ultrasonicated 4 times in ultrapure water for 15 min and dried under vacuum.

The functionalized graphite felt was placed in $50 \mathrm{~mL}$ anhydrous dichloromethane in a reactor under argon at $0^{\circ} \mathrm{C} .0 .5 \mathrm{~mL}$ of DAST were added and the solution was stirred at room temperature for $5 \mathrm{~h}$. The felts were rinsed in anhydrous dichloromethane and then, the electrode was placed in a solution of anhydrous dichloromethane, $1 \mathrm{~mL}$ of triethylamine and $100 \mathrm{mg}$ of 4-nitrobenzylamine hydrochloride or cyclam under argon. The solution was stirred at room temperature for $24 \mathrm{~h}$. The modified electrodes were ultrasonicated two times with dichloromethane and two times with acetone for $15 \mathrm{~min}$.

\subsection{Preconcentration of copper}

Copper ions were accumulated at the electrode (cylinder with diameter of $1 \mathrm{~cm}$ and thickness of $12 \mathrm{~mm}$ ) at open circuit potential by flowing an aqueous solution of anhydrous copper (II) chloride through the electrode in a flow reactor at $20 \pm 1^{\circ} \mathrm{C}$. The volumes and flow rates are 
given in the text. The electrode was then removed and transferred to a standard cell for linear sweep stripping voltammetry analysis (LSSV).

\subsection{Instrumentation}

Controlled potential electrolyses were performed in a divided flow cell, fitted with a graphite felt electrode (10 mm diameter, $12 \mathrm{~mm}$ thickness) located between two counter electrodes. Two cationic exchange membranes (Ionac 3470) were used for cell division. The reference electrode (Saturated Calomel Electrode, SCE) was positioned at the top of the cell surface of the felt, at an equal distance from the entry and the exit of the cell.

Voltammetric experiments were carried out using a VersaSTAT3 AMETEK Model (Princeton Applied Research) potentiostat/galvanostat or an AUTOLAB PGSTAT 302N (Ecochemie, The Netherlands) equipped with the associated NOVA 1.10 software. For electrochemical analyses performed in a standard three-electrode configuration, a graphite felt working electrode (cylinder of diameter $1 \mathrm{~cm}$ and thickness $12 \mathrm{~mm}$ ) fixed to a platinum wire, a platinum wire auxiliary electrode, and a saturated calomel reference electrode (SCE) were used. The electrodes modified by nitro compounds were analyzed in degassed $0.5 \mathrm{M} \mathrm{H}_{2} \mathrm{SO}_{4}$ under nitrogen. First, electroreduction of the nitro group into hydroxylamine was performed by cycling the potential twice between 0 and $-0.5 \mathrm{~V}_{\mathrm{SCE}}$ at $0.1 \mathrm{~V} \mathrm{~s}^{-1}$ and then, the nitrosohydroxylamine reversible system was observed by cycling the potential between 0 and 0.6 $\mathrm{V}_{\mathrm{SCE}}$.

The electrochemical analyses in flow were carried out in a flow electrochemical cell. Linear sweep stripping voltammetry analyses (LSSV) were performed in ultrapure water, containing $0.1 \mathrm{M} \mathrm{NaBF}_{4}$, at a $100 \mathrm{mV} \mathrm{s}^{-1}$ scan rate, under a dinitrogen atmosphere, with deposition potential of $-0.5 \mathrm{~V}_{\mathrm{SCE}}$ and deposition time of $200 \mathrm{~s}$.

XPS analyses were performed under a base pressure of $7 \times 10^{-10} \mathrm{mbar}$, using a VSW HA100 spectrometer. The analyzer was operated with constant pass energy of $22 \mathrm{eV}$. X-ray source used $\mathrm{Mg} \mathrm{K \alpha}$ excitation radiation at $1283.6 \mathrm{eV}$. The spectrometer binding energy scale was initially calibrated against the Au 4f $(84.0 \mathrm{eV})$ level. C1s level $(284.4 \mathrm{eV})$ on fresh graphite felt served as a reference for all spectra.

\section{Results and discussion}

\subsection{Derivatization of the graphite felt}


Three graphite felt electrodes were derivatized according to different methods involving electrogenerated radicals. The first one consisted in the anodic oxidation of 5-aminopentanoic acid $\mathbf{1}$ at $0.8 \mathrm{~V}_{\mathrm{SCE}}$ in a $\mathrm{pH} 10.3$ carbonate $(0.5 \mathrm{M})$ buffer solution for $2 \mathrm{~h}$ (Scheme 1: route 1) [29].

\section{Scheme 1}

In the second one, 6-amino-hexanoic acid methyl ester $\mathbf{2}$ (Scheme 1: route 2) was oxidized at 1.2 $\mathrm{V}_{\mathrm{SCE}}$ in $0.5 \mathrm{M} \mathrm{Bu}_{4} \mathrm{NBF}_{4}$ acetonitrile for $1 \mathrm{~h}$. The ester $\mathbf{2}$ was used to avoid problems linked to the solubility of $\mathbf{1}$ in acetonitrile. Whereas the electrografting in aqueous solutions is easier to carry out with the flow electrochemical cell, the electrografting of the amino linker was also performed in organic media since it has been previously observed that the reaction was more efficient in acetonitrile on PPF surfaces [34]. Surfaces modified by the electrochemical grafting of $\mathbf{2}$ were then saponified with $\mathrm{NaOH}$. The last method involved the electrochemical reduction of 4-carboxymethyl-benzenediazonium salts 3 at $-0.2 \mathrm{~V}_{\mathrm{SCE}}$ in $0.5 \mathrm{M} \mathrm{HCl}$ for 5 min [39].

The passivation of the modified graphite fibers was investigated by cyclic voltammetry using potassium ferricyanide as a redox probe. Fig. 1 shows a cyclic voltammogram of $1 \mathrm{mM}$ potassium ferricyanide in a $0.05 \mathrm{M}$ phosphate buffer $\mathrm{pH} 7.0$ at a scan rate of $0.1 \mathrm{~V} \mathrm{~s}^{-1}$, at a graphite electrode before and after modification.

\section{Figure 1}

The redox peaks of ferricyanide observed with unmodified graphite felt decreased with the electrode modified according to route 1 and 2 and almost disappeared when the electrografting process involves aryl diazonium salts (route 3). This blocking effect confirms the presence of a molecular layer on the graphite fibers and seems to show a better surface coverage with route 3 . Indeed, the reduction of diazonium salts is known to give multilayers [33], assuring the formation of a compact molecular film on the entire electrode surface.

The volume concentrations of grafted species were then estimated using nitro species. The carboxyl group was first activated by DAST and then was allowed to react with 4nitrobenzylamine. The presence of immobilized compounds was ascertained by the appearance of the nitroso-hydroxylamine reversible system formed after electroreduction of the nitro group at $-0.5 \mathrm{~V}_{\mathrm{SCE}}$. The volume concentrations of the grafted molecules were 
obtained by integration of the cyclic voltammograms (Fig. 2) using the Faraday law and are given in Table 1.

Figure 2

Table 1

The results confirm the experiments with ferricyanide (Fig. 1). The volume concentrations of immobilized species according to route 1 and 2 were in the same order of magnitude, whereas higher values were obtained with route 3 , confirming the better surface coverage with the cathodic reduction of diazonium salts.

The graphite felts were also analyzed by XPS. A F1s signal was observed after grafting by the three methods and activation with DAST (Fig. 3 and Table 2).

Figure 3

Table 2

After deconvolution, the F1s spectra exhibited two peaks at 685.7-686.2 and 687.4-687.8 eV for all the procedures (Table 2). It has been reported that the F 1s level between 685.7 and $686.6 \mathrm{eV}$ corresponds to semi-ionic bonds [40-42] also interpreted as covalent C-F bonds involved in the hyperconjugaison of a conjugated double bonds network [43, 44]. The peak at 685.7-686.2 eV can be interpreted in our case by an interaction (semi-ionic or covalent) between a fluorine atom and the graphite surface of the felt or the aryl film formed in route 3. The second peak can be assigned to the COF group, since the binding energy of covalent C-F bonds varies from 687 to $690 \mathrm{eV}$ [41, 45, 46]. After reaction with 4-nitrobenzylamine, a decrescence of the F1s signal was clearly observed (Fig. 3). The second peak, attribuated to the COF group decreased significantly for graphite felts modified according to route 1 and 3, which underlined the effectiveness of the coupling reaction. However, for route 2, the component at $687.8 \mathrm{eV}$, attribuated to the COF group is smaller than the peak at $686.0 \mathrm{eV}$. This result suggests that the grafting process was less efficient for route 2. It is in accordance with cyclic voltammetry, which gives a lower volume concentration of immobilized nitro species. The presence of nitro groups at the graphite surface was confirmed by the peak at 
406-407 eV for the three grafting methods, as exemplified in Fig. 4 for the modification according to route 2 .

Figure 4

The lower efficiency and the more difficult establishement (higher number of steps, organic medium) of the grafting process performed with 6-amino-hexanoic acid methyl ester 2 (route 2) led us to consider only routes 1 and 3 in the following experiments.

\subsection{Effect of the modification of the electrodes on the copper response}

The analysis of the copper (II) solution was carried out in two steps. First, the preconcentration of ions on the porous electrode was performed by flowing $300 \mathrm{~mL}$ of a $10^{-8}$ $\mathrm{M} \mathrm{Cu}^{2+}$ solution through the modified electrodes in a flow reactor at open circuit. Second, the felt was transferred in a standard three-electrode cell and analyzed by LSSV in a $0.5 \mathrm{M}$ aqueous solution of $\mathrm{NaBF}_{4}$. Trapped $\mathrm{Cu}^{2+}$ ions were first reduced at $-0.5 \mathrm{~V}_{\text {SCE }}$ for $200 \mathrm{~s}$ and then the potential was varied from -0.5 to $0.8 \mathrm{~V}_{\mathrm{SCE}}$, leading to the apparition of well-defined peaks between 0.15 and $0.20 \mathrm{~V}_{\text {SCE }}$ (Fig. 5).

Figure 5

The volume concentrations of $\mathrm{Cu}^{2+}$ ions trapped into the graphite felt can be obtained by integration of the voltammograms, using the Faraday law (Table 3).

\section{Table 3}

A low signal was observed on the unmodified graphite felt. This result can be explained by the presence of residual carboxylate groups on the carbon fibers that are known to complex metallic cations [10]. This is confirmed by the enhancement of the electrochemical signal after addition of $\mathrm{COOH}$ groups on the electrode according to route 1 and 3 . Whereas the electrografting was more effective when the modification is performed by cathodic reduction of 4-carboxymethyl-benzenediazonium salts (route 3), the volume concentrations were higher with the electrode modified by anodic oxidation of 5-amino-pentanoic acid (route 1). Since both derivatization processes led to the formation of $\mathrm{COOH}$ groups on the electrode surface, a 
possible explanation is the presence of $\mathrm{NH}$ groups and the high flexibility of the carbon chain in 5-amino-pentanoic acid that allow a better complexation of $\mathrm{Cu}^{2+}$ ions by the linker. The volume concentration (Table 3: $4.44 \times 10^{-8} \mathrm{~mol} \mathrm{~cm}^{-3}$ ) is significantly higher than the value (Table 1: $0.57 \times 10^{-8} \mathrm{~mol} \mathrm{~cm}^{-3}$ ) obtained after immobilization of 4-nitrobenzylamine 4, showing a complexation of more than one copper ion per linker. However, in both cases, the reproducibility is low, underlining the low interest of these molecules to be used as a preconcentration layer for sensing. Afer the reaction with cyclam, the highest volume concentration of trapped copper (II) is obtained for the electrode modified according to route $3\left(7.83 \times 10^{-9} \mathrm{~mol} \mathrm{~cm}^{-3}\right)$. The ratio (around 1:2.5) of the volume concentrations of $\mathrm{Cu}^{2+}$ ions trapped by the cyclam-modified electrode prepared by route 1 to the electrode prepared by route 3 (Table 3 ) is similar to the ratio of the volume concentrations previously estimated using nitro species (Table 1). If the formation of a 1:1 cyclam/copper complex is assumed, this result shows that the difference of volume concentrations of trapped $\mathrm{Cu}^{2+}$ ions is only due to the efficiency of the grafting process. Thus, even if the derivatization process using cathodic reduction of diazonium salts leads to multilayer formation that can decrease the reading of trapped electroactive molecules, the resulting cyclam-modified electrode is more sensitive for sensing than the electrode prepared from the oxidation of the amino linker known to give rise to submonolayer coverage.

The dependence of the volume concentration of trapped copper on the concentration of the analyzed solution is given in Fig. 6.

Figure 6

Since the preconcentration step involves an equilibrium process, the dependence between the electrochemical signal and the concentration of copper is nonlinear and reached a plateau [10], following a Langmuir-like relation when performed at the equilibrium [8]. Results exhibited in Fig. 6 seem to show that the plateau is reached for copper concentrations in the range of $10^{-8}-10^{-9} \mathrm{M}$ for all the modified electrodes. A low signal between $2-5 \times 10^{-10} \mathrm{~mol} \mathrm{~cm}^{-}$ ${ }^{3}$ was obtained for copper concentrations of $10^{-10} \mathrm{M}$, showing that the sensors can be used to measure copper concentrations between $10^{-10}$ and $10^{-9} \mathrm{M}$. Since the precision of the sensor will be linked to the wide current range (or volume concentration range) obtained for copper concentrations between $10^{-10}$ and $10^{-9} \mathrm{M}$, the most precise sensors are those prepared by route 1 and route $3+$ cyclam. 
To complete the comparison of the four modified electrodes, their selectivity was investigated in the presence of $\mathrm{Pb}^{2+}$ as a common metal ion interferent known to be complexed by carboxylate groups [10] and cyclam [29]. A $10^{-8} \mathrm{M}$ solution of $\mathrm{Cu}^{2+}$ and $\mathrm{Pb}^{2+}$ was percolated through the porous electrode for $30 \mathrm{~min}$ at $10 \mathrm{~mL} \mathrm{~min}^{-1}$. LSSV analysis in $0.5 \mathrm{M} \mathrm{NaBF}_{4}$ and resulting volume concentrations of trapped copper are given in Fig. 7.

\section{Figure 7}

As expected, $\mathrm{Pb}^{2+}$ interfered with $\mathrm{Cu}^{2+}$ ions for all the electrodes. However, the selectivity depends on the nature of the modified electrode. For the electrodes modified according to route 1 and 3, the signal decreased dramatically, especially with the amino linker. For the cyclam-modified electrodes, the decrease of the signal was less important, showing the interest to use a specific receptor to improve the selectivity of the sensor. Moreover, the electrode modified by route 1 + cyclam is less sensitive to the presence of lead than the electrode modified by route $3+$ cyclam. This result can be explained by the high flexibility of 5-amino-pentanoic acid linker, allowing cyclam to adopt the best conformation to achieve copper complexation.

\section{Conclusions}

Electrografting methods involving reduction of diazonium salts and oxidation of amines in organic and aqueous media were used to prepare carboxylate and cyclam-modified electrodes. The efficiency of the immobilization methods was checked by cyclic voltammetry using redox probes and by XPS analyses. Higher volume concentrations were obtained with the process related to cathodic reduction of diazonium salts. The performances of the modified electrodes for trace analysis of copper were then evaluated in terms of sensitivity and selectivity. A higher electrochemical signal was observed with the electrode modified with cyclam via cathodic reduction of diazonium salts, showing that the effect of surface coverage on the sensor response is more important than the influence of the multilayer grafting process on the electron transfer. However, when a less selective receptor as carboxylate group is used, the linker structure can interfere in the complexation reaction, as observed with the amino linker. The selectivity estimated in the presence of lead as a common ion interferent underlined the interest of a more elaborated receptor like cyclam compared with carboxyl linkers. Interestingly, the cyclam-modified electrodes did not exhibit the same selectivity despite the fact that they have the same receptor. A higher selectivity was obtained with the 
electrode modified by an amino linker, showing the importance of the nature of the linker on the efficiency of the complexation reaction.

\section{Acknowledgements.}

This paper was published under the frame of European Social Found, Human Resources Development Operational Programme 2007-2013, project no. POSDRU/159/1.5/S/136893. The authors are also thankful for the financial support to "Iuliu Hatieganu" University of Medicine and Pharmacy of Cluj-Napoca, for the research grant 1491/8/28.01.2014 and for their help to Ioana Băjan, Ana Gui and Ioana Ionel, students of "Iuliu Hatieganu" University of Medicine and Pharmacy, Faculty of Pharmacy.

\section{References}

[1] B. Klaue, J. D. Blum, Anal. Chem. 71 (1999) 1408-1414.

[2] R. N. Rao, M. V. N. K. Talluri, J. Pharm. Biomed. Anal. 43 (2007) 1-13.

[3] D. W. Arrigan, Analyst 119 (1994) 1953-1966.

[4] S. Ramezani, M. Ghobadi, B. N. Bideh, Sens. Actuators, B 192 (2014) 648-657.

[5] D. W. M. Arrigan, G. Svehla, S. J. Harris, M. A. McKervey, Electroanalysis 6 (1994) 97-106.

[6] K. C. Honeychurch, J. P. Hart, D. C. Cowell, D. W. M. Arrigan, Electroanalysis 14 (2002) 177-185.

[7] E. Chow, E. L. S. Wong, O. Pascoe, D. B. Hibbert, J. J. Gooding, Anal. Bioanal. Chem. 387 (2007) 1489-1498.

[8] G. Liu, Q. T. Nguyen, E. Chow, T. Bocking, D. B. Hibbert, J. J. Gooding, Electroanalysis 18 (2006) 1141-1151.

[9] M. Heitzmann, C. Bucher, J. C. Moutet, E. Pereira, B. L. Rivas, G. Royal, E. SaintAman, Electrochim. Acta 52 (2007) 3082-3087.

[10] R. Nasraoui, D. Floner, F. Geneste, J. Electroanal. Chem. 629 (2009) 30-34.

[11] R. Nasraoui, D. Floner, F. Geneste, Electrochem. Commun. 12 (2010) 98-100.

[12] B. Feier, I. Bajan, I. Fizesan, D. Floner, C. Cristea, F. Geneste, R. Sandulescu, Int. J. Electrochem. Sci. 10 (2015) 121-139.

[13] F. Bettazzi, C. Giorgi, S. Laschi, I. Palchetti, Electroanalysis 24 (2012) 591-599.

[14] M. M. Musameh, D. Klink, J. Choi, Y. B. Truong, I. L. Kyratzis, Electroanalysis 24 (2012) 1207-1211. 
[15] L. Chen, Z. Li, Y. Meng, P. Zhang, Z. Su, Y. Liu, Y. Huang, Y. Zhou, Q. Xie, S. Yao, Sens. Actuators, B 191 (2014) 94-101.

[16] R. G. B. Bouwe, I. K. Tonle, S. Letaief, E. Ngameni, C. Detellier, Appl. Clay Sci. 52 (2011) 258-265.

[17] I. K. Tonlé, S. Letaief, E. Ngameni, A. Walcarius, C. Detellier, Electroanalysis 23 (2011) 245-252.

[18] A. Afkhami, F. Soltani-Felehgari, T. Madrakian, H. Ghaedi, M. Rezaeivala, Anal. Chim. Acta 771 (2013) 21-30.

[19] S. Morante-Zarcero, A. Sánchez, M. Fajardo, I. del Hierro, I. Sierra, Microchim. Acta 169 (2010) 57-64.

[20] A. Sanchez, S. Morante-Zarcero, D. Perez-Quintanilla, I. Sierra, I. del Hierro, Sens. Actuators, B 163 (2012) 38-43.

[21] A. Sanchez, A. Walcarius, Electrochim. Acta 55 (2010) 4201-4207.

[22] G. Herzog, N. A. Vodolazkaya, A. Walcarius, Electroanalysis 25 (2013) 2595-2603.

[23] G.-O. Buica, E.-M. Ungureanu, L. Birzan, A. C. Razus, M.-R. Bujduveanu, Electrochim. Acta 56 (2011) 5028-5036.

[24] E. Pereira, B. L. Rivas, M. Heitzman, J.-C. Moutet, C. Bucher, G. Royal, E. Saint Aman, Macromol. Symp. 304 (2011) 115-125.

[25] G. K. Raghu, S. Sampath, M. Pandurangappa, J. Solid State Electrochem. 16 (2012) 1953-1963.

[26] M. L. Yola, N. Atar, M. S. Qureshi, Z. Üstündag, A. O. Solak, Sens. Actuators, B 171172 (2012) 1207-1215.

[27] R. G. Kempegowda, P. Malingappa, Sens. Actuators, B 186 (2013) 478-485.

[28] B. S. Flavel, M. Nambiar, J. G. Shapter, Silicon 3 (2011) 163-171.

[29] R. Nasraoui, D. Floner, C. Paul-Roth, F. Geneste, J. Electroanal. Chem. 638 (2010) 914.

[30] B. Feier, D. Floner, C. Cristea, R. Sandulescu, F. Geneste, Electrochem. Commun. 31 (2013) 13-15.

[31] A. Sánchez, S. Morante-Zarcero, D. Pérez-Quintanilla, I. del Hierro, I. Sierra, J. Electroanal. Chem. 689 (2013) 76-82.

[32] B. Feier, D. Floner, C. Cristea, E. Bodoki, R. Sandulescu, F. Geneste, Talanta 98 (2012) 152-156.

[33] D. Bélanger, J. Pinson, Chem. Soc. Rev. 40 (2011) 3995-4048. 
[34] R. Nasraoui, J.-F. Bergamini, S. Ababou-Girard, F. Geneste, J. Solid State Electrochem. 15 (2011) 139-146.

[35] S. Goubert-Renaudin, M. Etienne, Y. Rousselin, F. Denat, B. Lebeau, A. Walcarius, Electroanalysis 21 (2009) 280-289.

[36] C. Bourdillon, J. Electroanal. Chem. 336 (1992) 113-123.

[37] C. Moinet, J. Phys. IV 4 (1994) 175-184.

[38] F. Geneste, M. Cadoret, C. Moinet, G. Jezequel, New J. Chem. 26 (2002) 1261-1266.

[39] R. Marion, G. Muthusamy, F. Geneste, J. Catal. 286 (2012) 266-272.

[40] A. Tressaud, E. Durand, C. Labrugère, J. Fluorine Chem. 125 (2004) 1639-1648.

[41] L. Jiang, R. Cheung, R. Brown, A. Mount, J. Appl. Phys. 93 (2003) 1376-1383.

[42] Y. Hattori, H. Kanoh, F. Okino, H. Touhara, D. Kasuya, M. Yudasaka, S. Iijima, K. Kaneko, J. Phys. Chem. B 2004 (2004) 9614-9618.

[43] D. Claves, New J. Chem. 35 (2011) 2477-2482.

[44] Y. Sato, K. Itoh, R. Hagiwara, T. Fukunaga, Y. Ito, Carbon 42 (2004) 3243-3249.

[45] H. Touhara, F. Okino, Carbon 38 (2000) 241-268.

[46] A. Tressaud, F. Moguet, S. Flandrois, M. Chambon, C. Guimon, G. Nanse, E. Papirer, V. Gupta, O. P. Bahl, J. Phys, Chem. Solids 57 (1996) 745-751.

Scheme and Figure captions

Scheme 1: Electrochemical and chemical modifications performed on the graphite felt electrode.

Figure 1: Cyclic voltammograms at graphite felt electrode of $1 \mathrm{mM} \mathrm{K}_{3}\left[\mathrm{Fe}(\mathrm{CN})_{6}\right]$ in $0.5 \mathrm{M}$ phosphate buffer $\mathrm{pH}=7$ before ( - ) and after grafting according to route 1 (-----), $2(\cdots)$ ) and $3(-)$. Scan rate $0.1 \mathrm{~V} \mathrm{~s}^{-1}$.

Figure 2: Typical voltammogram of $\mathrm{NHOH} / \mathrm{NO}$ system obtained in $0.5 \mathrm{M} \mathrm{H}_{2} \mathrm{SO}_{4}$ for nitro species present on the graphite surface, after reduction of $\mathrm{NO}_{2}$ into $\mathrm{NHOH}$ at $-0.5 \mathrm{~V}_{\mathrm{SCE}}$. Scan rate: $0.1 \mathrm{~V} \mathrm{~s}^{-1}$. Only the bottom of the wave (e.g. hatched area) was considered for calculation of the surface concentration using the Faraday law. 
Figure 3: XPS spectra of the F 1s region after reaction with DAST (-o-) and after reaction with 4-nitrobenzylamine (-m-) for route 1 (a), route 2 (b) and route 3 (c). The curves have been background subtracted and normalised with respect to carbon peak.

Figure 4: XPS spectra of the $\mathrm{N}$ 1s region after reaction with 4-nitrobenzylamine exemplified here with route 2 . The curves have been background subtracted.

Figure 5: Voltammograms of $\mathrm{Cu}^{2+}$ trapped on an unmodified graphite felt electrode (----), and

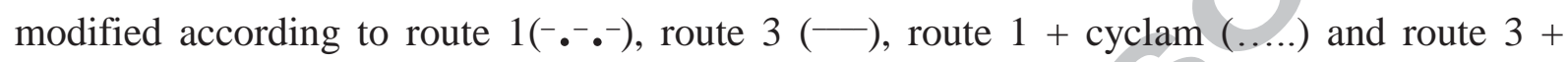
cyclam (-). The preconcentration step was performed at $10 \mathrm{~mL} \mathrm{~min}^{-1}$ with a $10^{-8} \mathrm{M}$ copper solution. LSSV analysis was carried out in a $0.5 \mathrm{M}$ aqueous solution of $\mathrm{NaBF}_{4}$ (reduction at $0.5 \mathrm{~V}_{\mathrm{SCE}}$ for $200 \mathrm{~s}$ and then the potential was varied from -0.5 to $0.5 \mathrm{~V}_{\mathrm{SCE}}$ ). Scan rate: $0.1 \mathrm{~V} \mathrm{~s}^{-}$ ${ }^{1}$ The inset shows a zoom-in view of the electrochemical signal for route 3 , route $1+$ cyclam and route $3+$ cyclam.

Figure 6: Volume concentrations of $\mathrm{Cu}^{2+}$ determined by LSSV analysis at the modified graphite felt electrodes and shown in a logarithmic scale as a function of $\mathrm{Cu}^{2+}$ concentration. LSSV analysis was carried out in a $0.5 \mathrm{M}$ aqueous solution of $\mathrm{NaBF}_{4}$ (reduction at $-0.5 \mathrm{~V}_{\mathrm{SCE}}$ for $200 \mathrm{~s}$ and then the potential was varied from -0.5 to $\left.-0.5 \mathrm{~V}_{\mathrm{SCE}}\right)$. Scan rate: $0.1 \mathrm{~V} \mathrm{~s}^{-1}$

Figure 7: A) Voltammograms of $\mathrm{Cu}^{2+}$ trapped on a modified graphite felt electrode after a preconcentration at $10 \mathrm{~mL} \mathrm{~min}^{-1}$ for $30 \mathrm{~min}$ in an aqueous solutions containing $10^{-8} \mathrm{M} \mathrm{Cu}^{2+}$ $(-)$ and $\mathrm{Cu}^{2+}+\mathrm{Pb}^{2+}$ (----) Scan rate: $0.1 \mathrm{~V} \mathrm{~s}^{-1} \mathrm{~B}$ ) Volume concentrations of copper (the ratio between the copper signal after addition of $\mathrm{Pb}^{2+}$ over the initial one is given in percent).

Table 1: Volume concentrations of the grafted linkers from nitro species concentrations estimated by cyclic voltammetry

\begin{tabular}{ll}
\hline Grafting process & $\begin{array}{l}\text { Volume concentration } \\
\times 10^{8}\left(\mathrm{~mol} \mathrm{~cm}^{-3}\right)\end{array}$ \\
\hline Route 1 & $0.57 \pm 0.06$ \\
Route 2 & $0.26 \pm 0.04$ \\
Route 3 & $1.43 \pm 0.17$ \\
\hline${ }^{a}$ Based on 2 sample measurements taken from the same grafted felt
\end{tabular}


Table 2: Deconvolution of the F1s signal for the graphite felts modified according to route 1, 2 and 3.

\begin{tabular}{|c|c|c|c|}
\hline Nature of the felt & Binding energy/eV & FWHM/eV ${ }^{\mathrm{a}}$ & \% Peak area ratio \\
\hline \multicolumn{4}{|l|}{ Route 1} \\
\hline \multirow[t]{2}{*}{ Before $\mathrm{NO}_{2}$} & 687.4 & 2.5 & 51 \\
\hline & 686.2 & 2.5 & 48 \\
\hline \multirow[t]{2}{*}{ After $\mathrm{NO}_{2}$} & 687.4 & 2.5 & 19 \\
\hline & 685.7 & 2.5 & 80 \\
\hline \multicolumn{4}{|l|}{ Route 2} \\
\hline \multirow{2}{*}{ Before $\mathrm{NO}_{2}$} & 687.8 & 2.5 & 16 \\
\hline & 686.0 & 2.5 & 84 \\
\hline \multirow[t]{2}{*}{ After $\mathrm{NO}_{2}$} & 687.4 & 2.5 & 32 \\
\hline & 685.5 & 2.5 & 68 \\
\hline \multicolumn{4}{|l|}{ Route 3} \\
\hline \multirow[t]{2}{*}{ Before $\mathrm{NO}_{2}$} & 687.6 & 2.5 & 66 \\
\hline & 685.9 & 2.5 & 34 \\
\hline \multirow[t]{2}{*}{ After $\mathrm{NO}_{2}$} & 687.6 & 2.5 & 26 \\
\hline & 685.9 & 2.5 & 74 \\
\hline
\end{tabular}

${ }^{\mathrm{a}}$ Full-Width Half-Maximum of peaks

Table 3: Volume concentrations of copper according to the nature of the modified electrode after preconcentration from $10^{-8} \mathrm{M}$ copper (II) solution

\begin{tabular}{ll}
\hline Electrode & $\begin{array}{l}\text { Volume concentrations } \times 10^{9} \\
\left(\mathrm{~mol} \mathrm{~cm}^{-3}\right)\end{array}$ \\
\hline Fresh felt & $0.55 \pm 0.07$ \\
Route 1 & $44 \pm 36$ \\
Route 3 & $2 \pm 1$ \\
Route $1+$ cyclam & $3.2 \pm 0.1$ \\
Route 3 + cyclam & $7.8 \pm 0.6$ \\
\hline${ }^{a}$ Based on 2 sample measurements taken in different grafted felts
\end{tabular}


Scheme 1
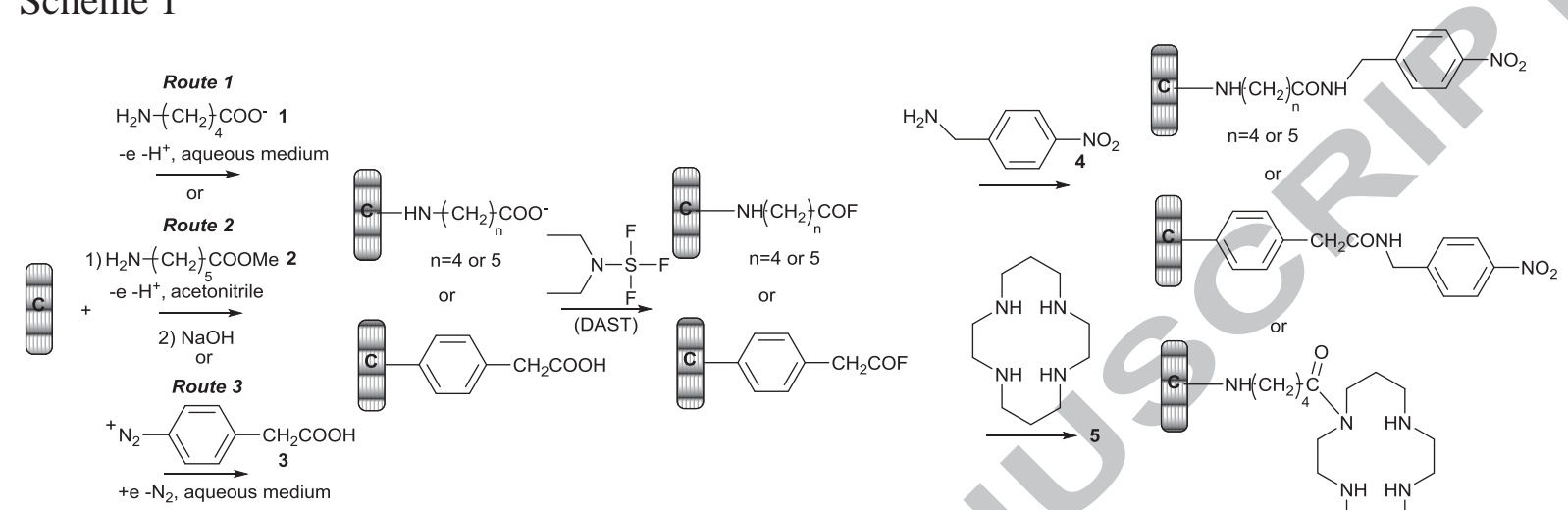

2) $\mathrm{NaOH}$

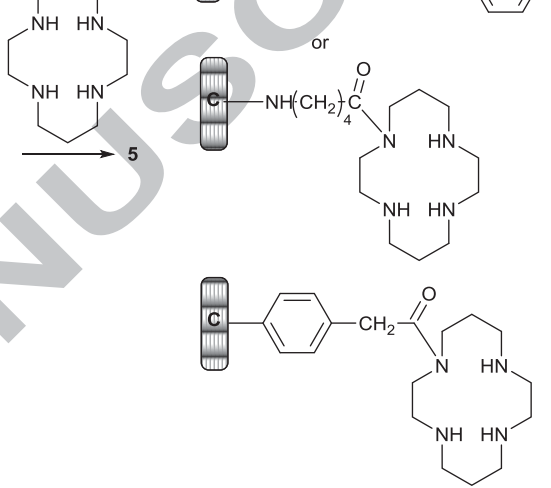


Figure 1

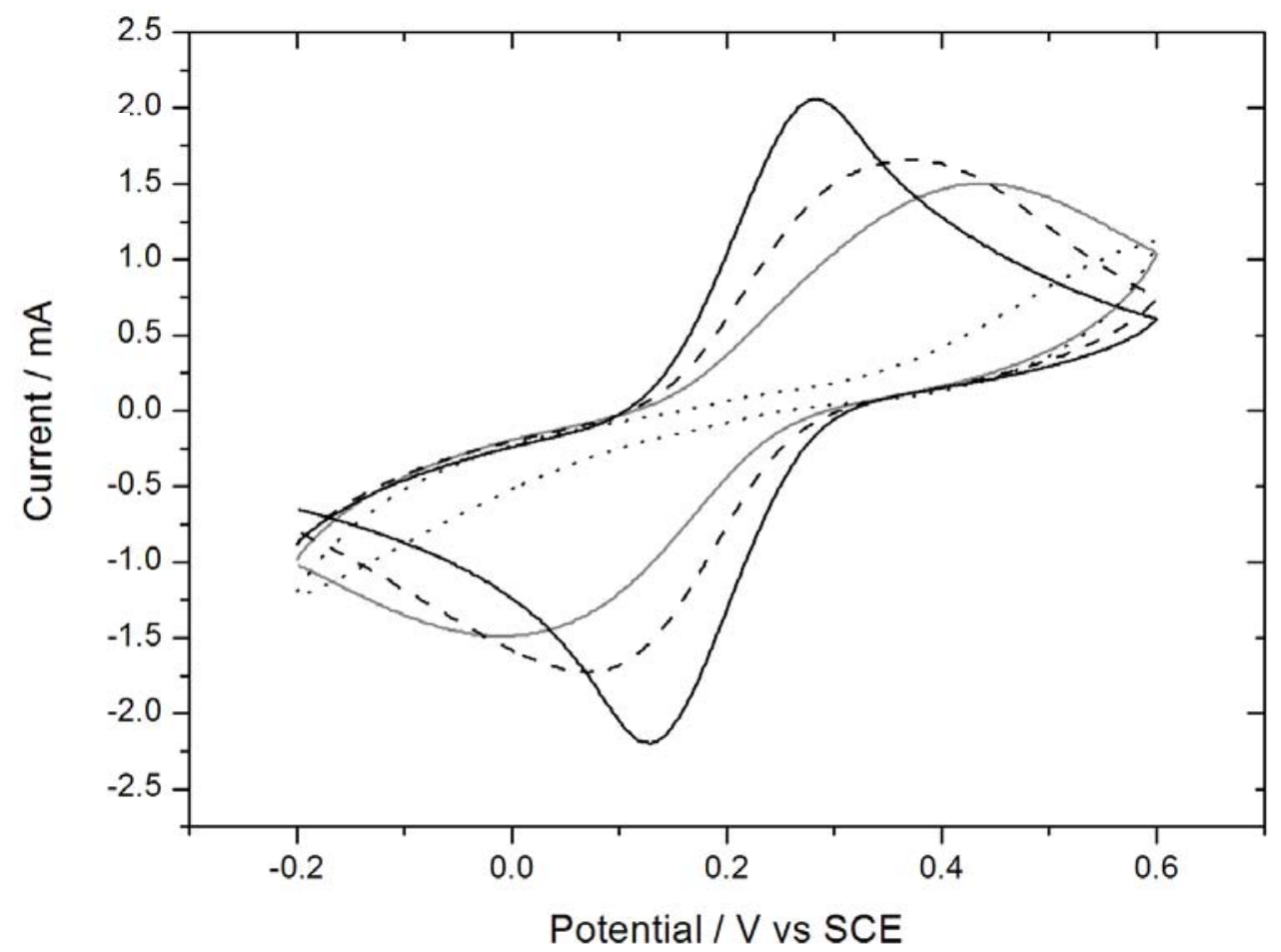


Figure 2

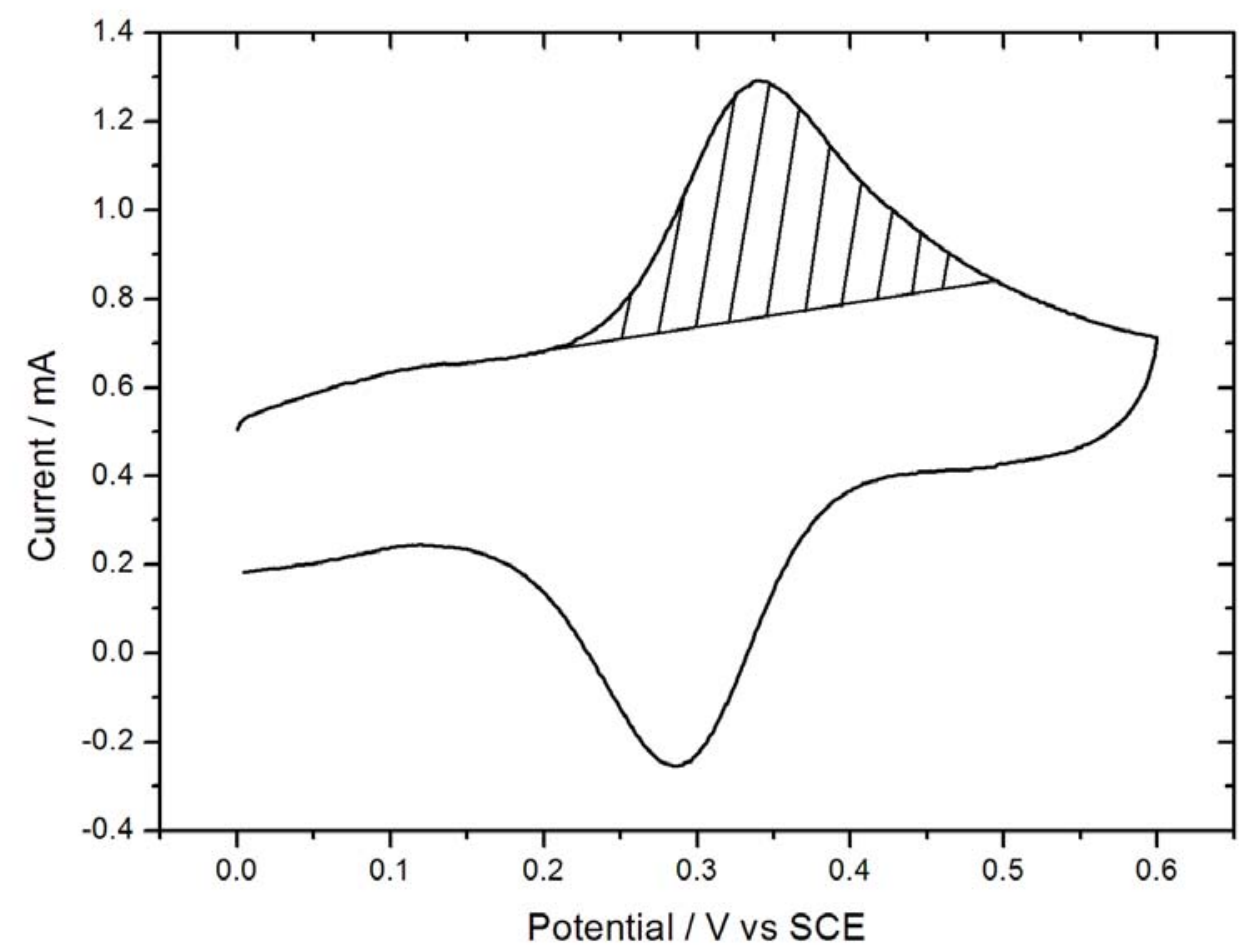


Figure 3
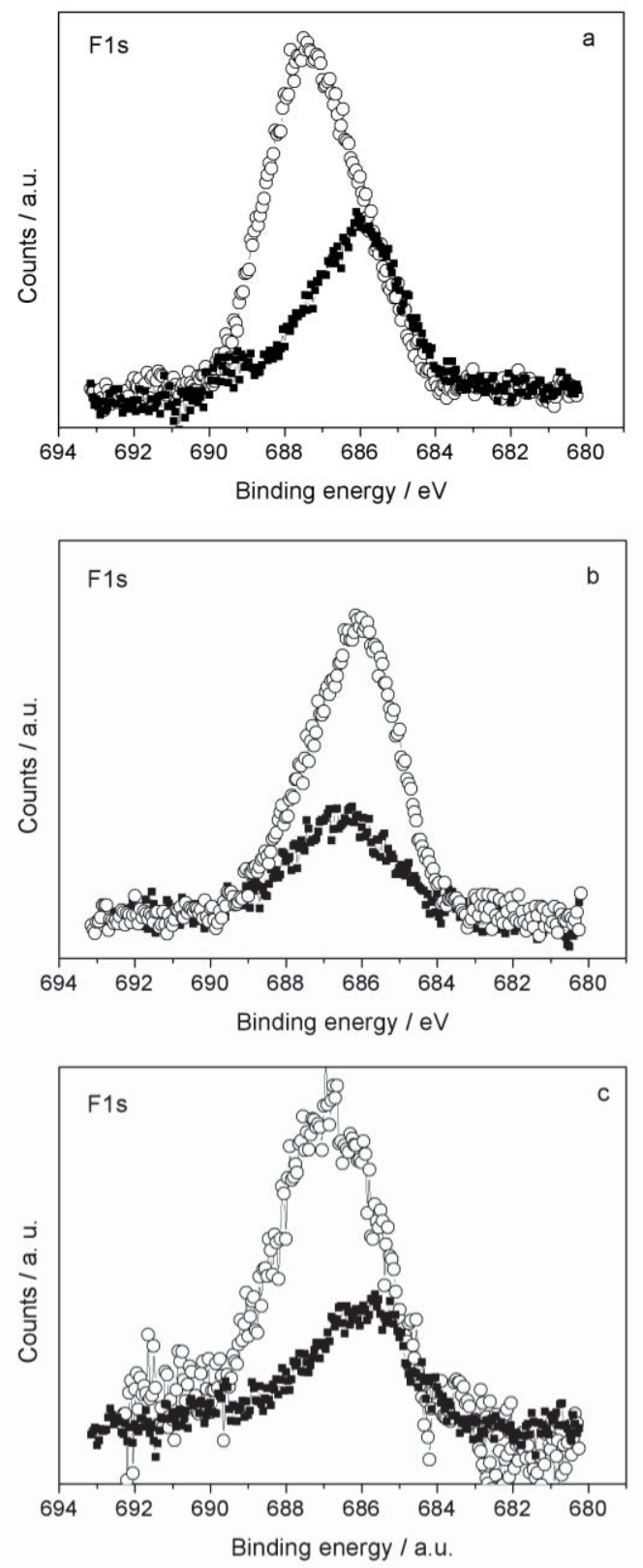
Figure 4

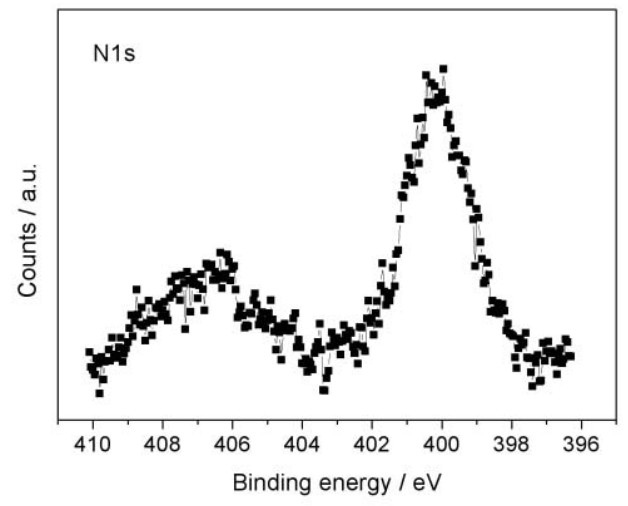


Figure 5

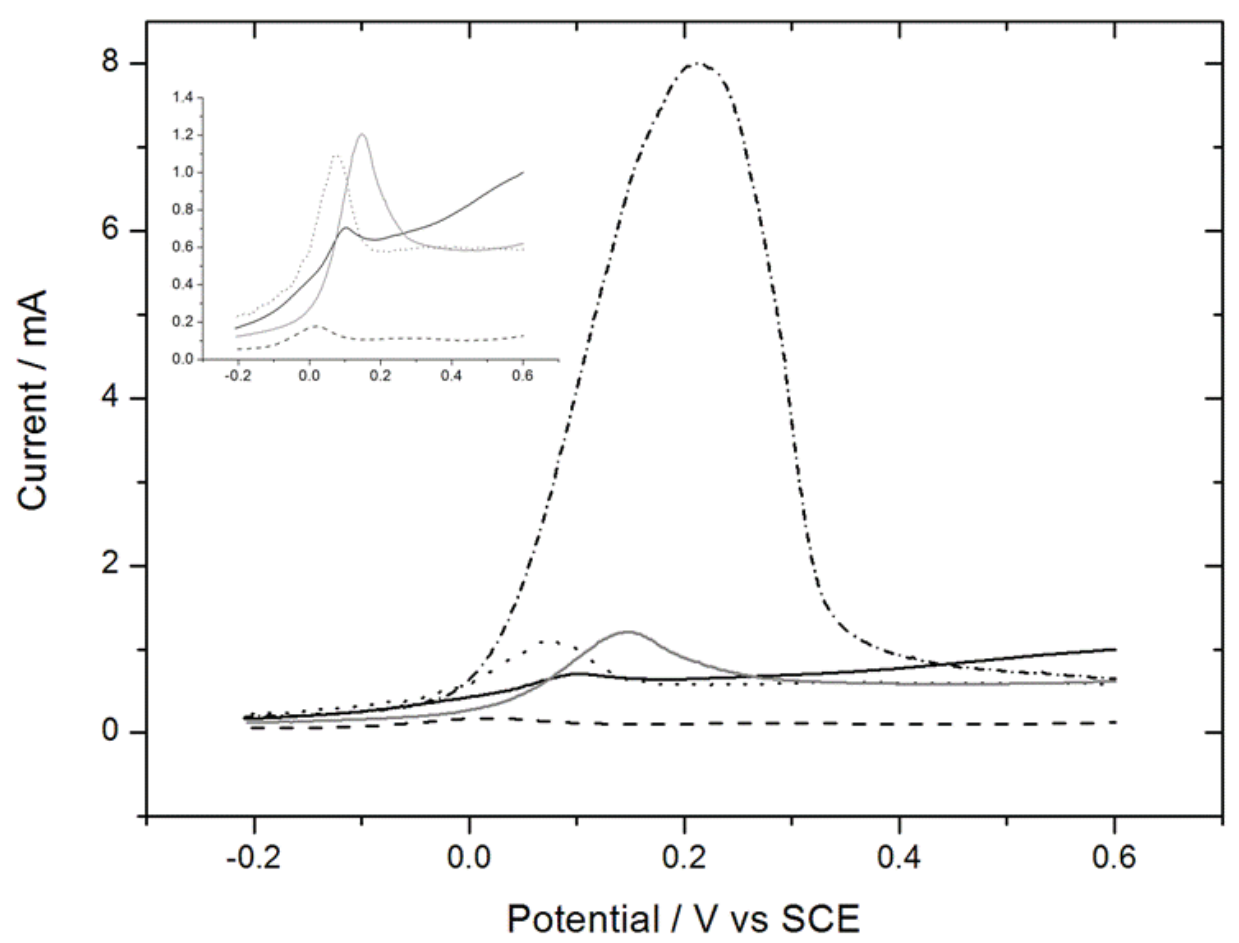


Figure 6

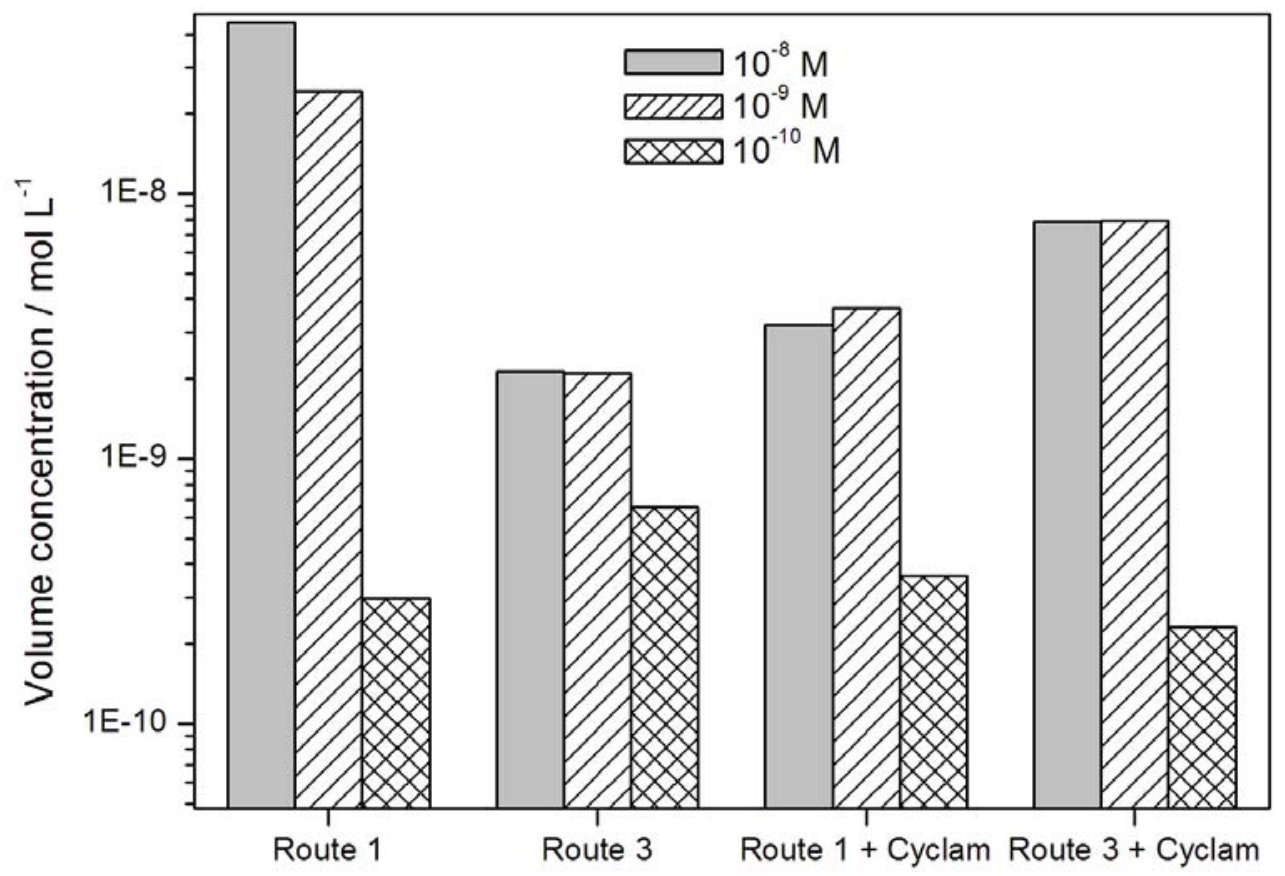


Figure 7

A
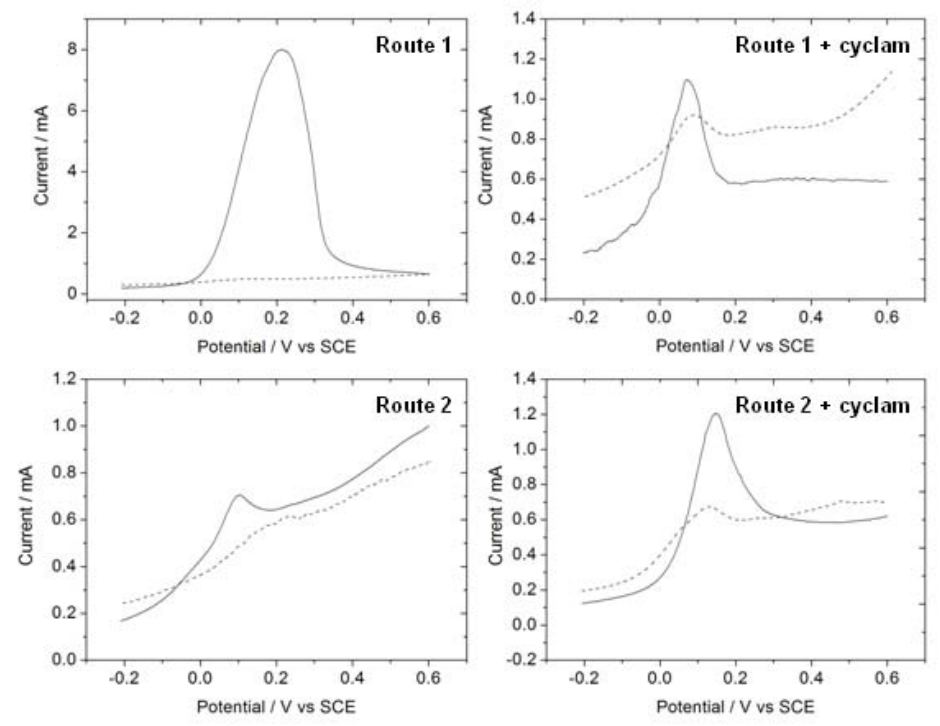

B

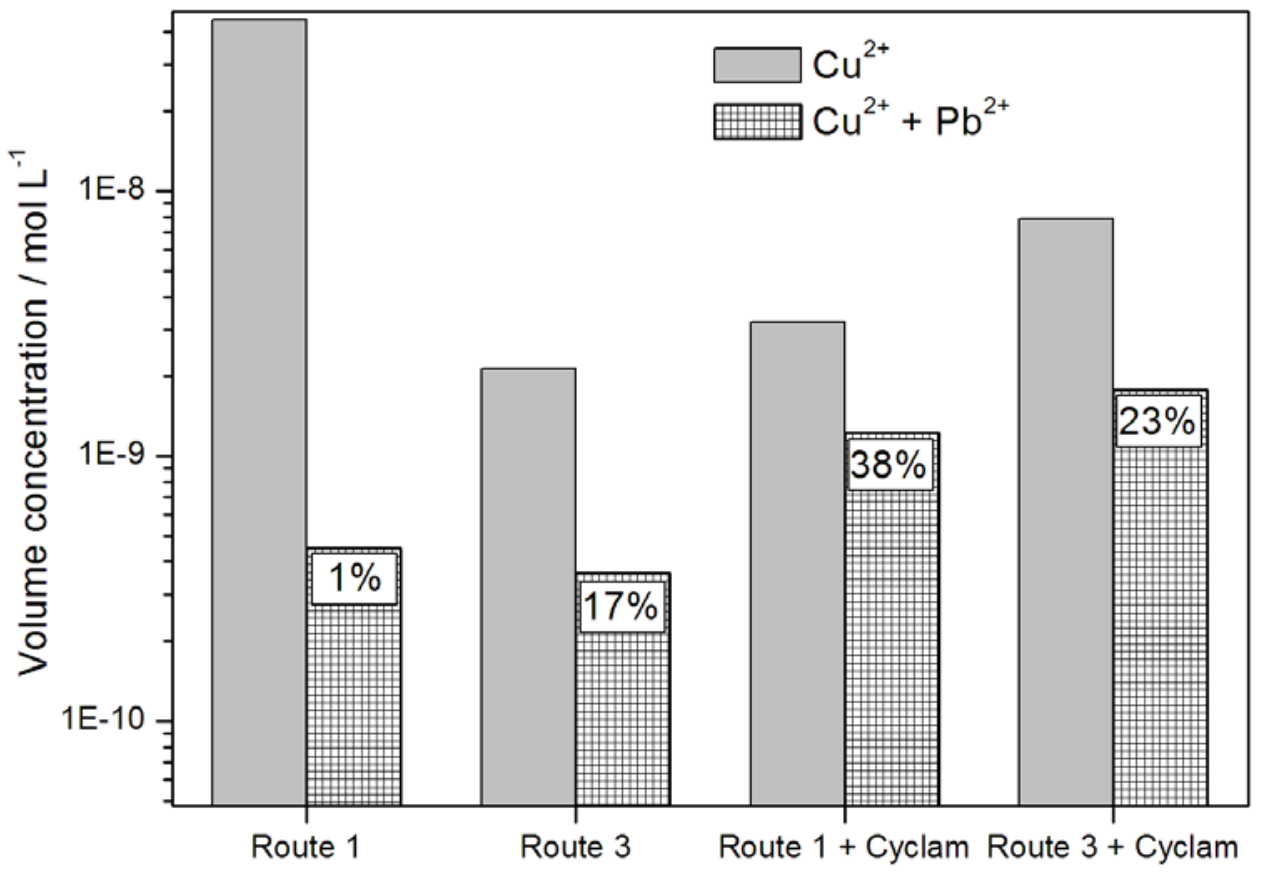


- Influence of the modification process of electrodes on their sensor properties

- The modified electrodes were characterized by electrochemical analysis and XPS

- For cyclam-modified electrodes, the signal increased with the surface coverage

- A more specific receptor enhanced the selectivity of the sensor

- The nature of the ligand can affect the signal and the selectivity of the sensor 


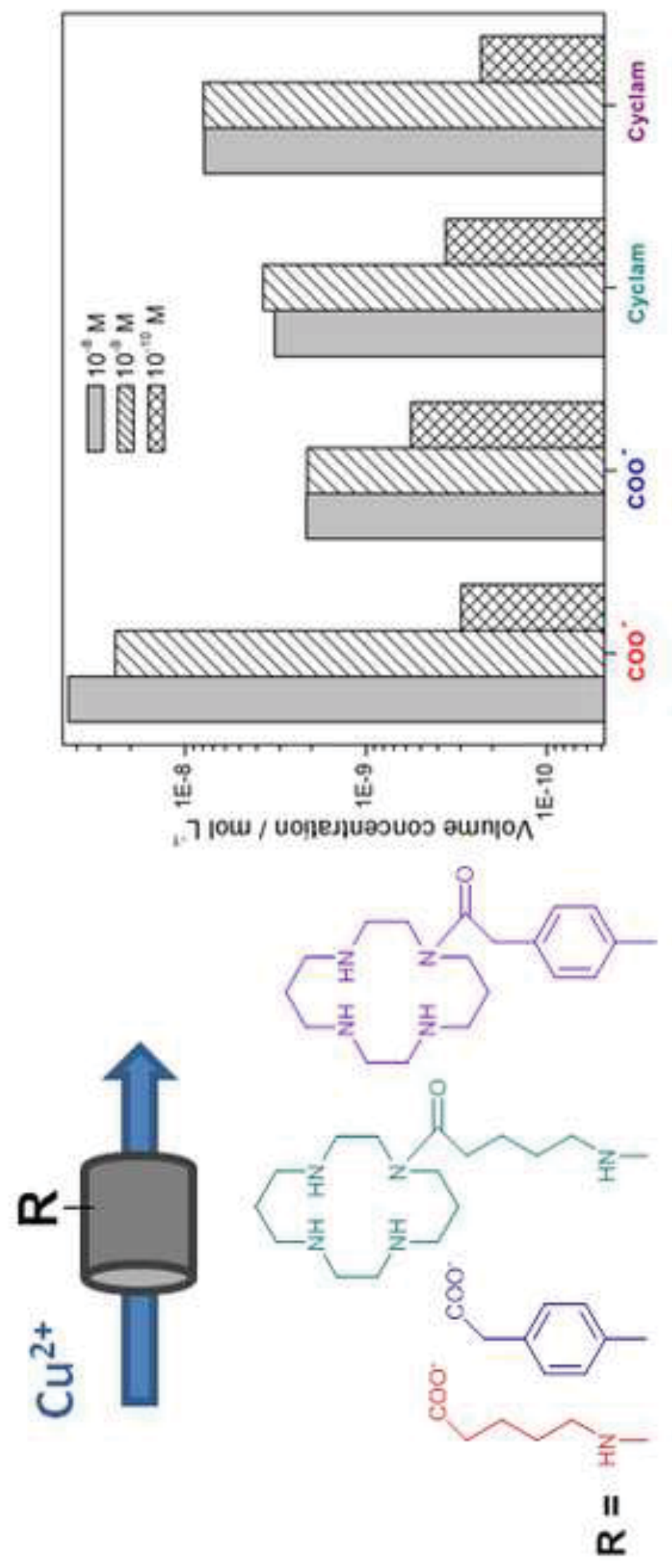

